\title{
OPEN Knowledge, awareness and practices of Pakistani professionals amid-COVID-19 outbreak
}

\author{
Samea Khan ${ }^{1,3}$, Usman Shah Gilani ${ }^{1,3}$, Syed Muhammad Muslim Raza ${ }^{2,3}$ \& \\ Tanveer Hussain ${ }^{1,3} \bowtie$
}

End of the year 2019 marks an unprecedented outbreak of a pandemic named COVID-19 caused by the SARS-CoV-2. It was first discovered in China and later spread to the whole world, currently inflicting almost 200 countries. After China, few other countries have emerged as potential epicenters of this disease including the US, Italy, Spain and Pakistan, as indicated by the World Health Organization (WHO). Since proper preventive and curative measures in the form of a vaccine or medication are currently unavailable throughout the world, the only remedy devised to stop the spread of this virus is self-isolation. Such a measure necessitates ample awareness and understanding among people to avoid actions that lead to the spread of this virus. Pakistan is the fifth-most populous country in the world (212.2 million) and has a record of contagious outbreaks in the past. Therefore, it is key to evaluate the general understanding regarding the cause, spread and control of this disease in Pakistani population and acquire data to anticipate the possible spread and persistence of this disease to design relevant preventive measures. We have attempted to collect such data from professionals who are susceptible to acquiring the infection due to an unavoidable exposure. Keeping in view the current lock down, we have relied on an internet based collection of data by filling a self-designed questionnaire that is responded to by 1132. Descriptive and Frequency Analysis were performed on the responses received using MS Excel and SPSS software. A total of 1132 individuals responded to the questionnaire among which include academic (45.8\%), non-academic $(20.8 \%)$, healthcare $(7.8 \%)$, security $(5.9 \%)$ and other (19.7\%) professionals. The questionnaire addressed the level of basic information regarding the cause, spread, cure and prevention of this disease among professionals, in an attempt to provide directions for awareness campaigns at different levels in Pakistan and provide a model for similar outbreaks in the future.To our expectations, almost after a month of the coronavirus outbreak in Pakistan, above $50 \%$ to up to $90 \%$ of the recorded responses against every question showed ample understanding regarding the cause, spread and control of the disease which is an indicator of effective public awareness campaigns throughout the country largely based on media drive.

Now declared a pandemic, initially COVID-19 was poorly identified as a disease caused by a novel virus and only reported as a cluster of pneumonia cases of unknown etiology from Wuhan, Hubei, Mainland China on 8th December $2019^{1}$. After preliminary investigation, it was believed to be caused due to a novel virus named SARS-CoV-2 that may have originated from an animal source in individuals who visited and/or consumed local seafood and animals in Wuhan ${ }^{2,3}$. Further spread of the disease to other countries and continents is attributed to vast traveling of non-symptomatic infected individuals, as reported by different countries ${ }^{4-6}$.

Currently around 200 countries and over half a million people are infected by the virus around the world. Despite rigorous efforts being put to develop a vaccine or drugs to counter coronavirus spread, current coping strategies are limited to self-isolation and general lock-downs. In this regard, Pakistan is facing a unique challenge due to poor screening capacity and consequential delay in implementing preventive measures, therefore

${ }^{1}$ Department of Molecular Biology, Virtual University of Pakistan, Lahore, Pakistan. ${ }^{2}$ Department of Quantitative Methods, School of Business and Economics, University of Management and Technology, Lahore, Pakistan. ${ }^{3}$ These authors contributed equally: Samea Khan, Usman Shah Gilani, Syed Muhammad Muslim Raza and Tanveer Hussain. ${ }^{\varpi}$ email: tanveer.hussain@vu.edu.pk 


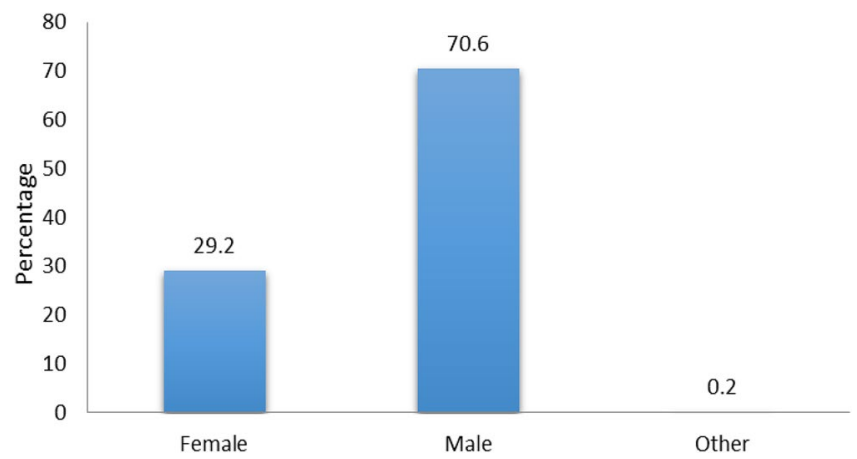

Figure 1. Percentage of gender wise responses. The bar chart represents percentages of respondents belonging to different genders.

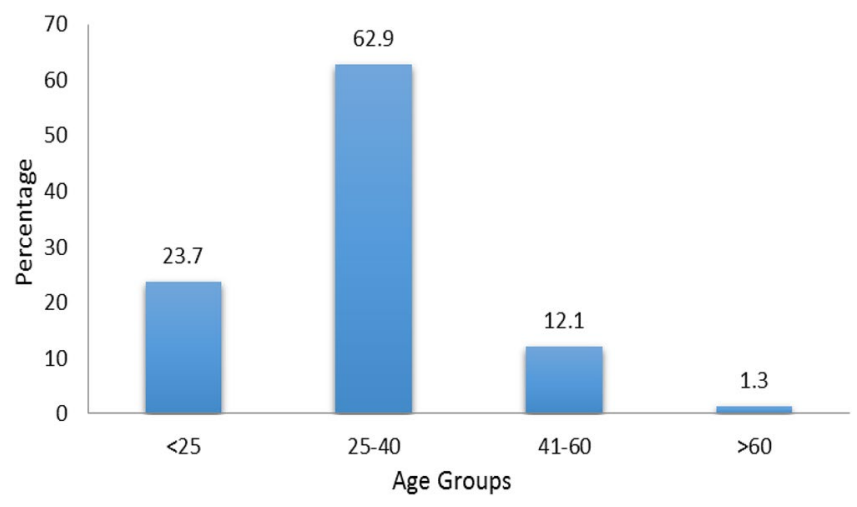

Figure 2. Percentage of age wise responses. The bar chart represents percentages of respondents belonging to different age groups.

apprehension that Pakistan is emerging as the next epicenter of this pandemic is expressed ${ }^{7,8}$. Awareness level and compliance of professionals play an important role in the effective and timely prevention and control of a public health crisis especially considering their increased susceptibility due to higher level of exposure to the environment and person-to-person interaction ${ }^{9}$. As a result, the National Action Plan for COVID-19 has been proposed by the Ministry of Health Services, Regulation and Coordination, Government of Pakistan for infection control, and a media campaign for generating awareness among the public has been initiated ${ }^{10}$. To bring about a comprehensive policy, teams from multi-disciplinary backgrounds are engaged including key frontlines to ensure effective their functioning ${ }^{11}$.

Keeping in view the importance of awareness and primary data that could help devise further control strategies, in this study, we have mainly aimed at evaluating the current level of awareness among professionals in Pakistan with regard to the cause, spread and cure of COVID-19. We have applied Descriptive and Frequency Analysis on data collected through an online medium by a self-designed questionnaire.

\section{Results}

Demographic distribution. A total of 1132 respondents comprising 331 (29.2\%) females and 799 (70.6\%) males participated in this survey (Fig. 1). Participants were divided into four age groups, group I was $<25$ years, group II was 25-40 years with the highest response percentage (62.9), group III was 41-60 years and group IV was $>60$ years with the least response percentage (1.3) (Fig. 2). Survey participants were divided into four groups on the basis of educational level, bachelor (33.2\%), Master/MPhil with the highest response percentage (58.7), $\mathrm{PhD}(7.7 \%)$ and only $0.4 \%$ response was obtained from others (Fig. 3). A survey response was gathered from different professions including academic staff with the highest frequency (45.8\%), non academic staff (20.8\%), healthcare professionals (7.8\%), security forces personnel being least (5.9\%) and others (19.7\%) (Fig. 4).

Question wise responses and percentages. To access the basic knowledge of COVID-19, an overwhelming majority of participants $(93.29 \%)$ were aware that it is a viral disease. In query regarding the prevalence of COVID-19, 39.19\% reported no case in their residing area, while $23.14 \%$ reported less than 10 cases, $10.07 \%$ reported $10-50$ cases, $13.34 \%$ reported more than 50 cases and $16.61 \%$ had no idea regarding it. When respondents were asked about the possible origin of COVID-19, the majority (45.41\%) was of the opinion that bat is the origin and $36.75 \%$ people were not sure. In a query about seasonality of COVID-19, $65.81 \%$ of 


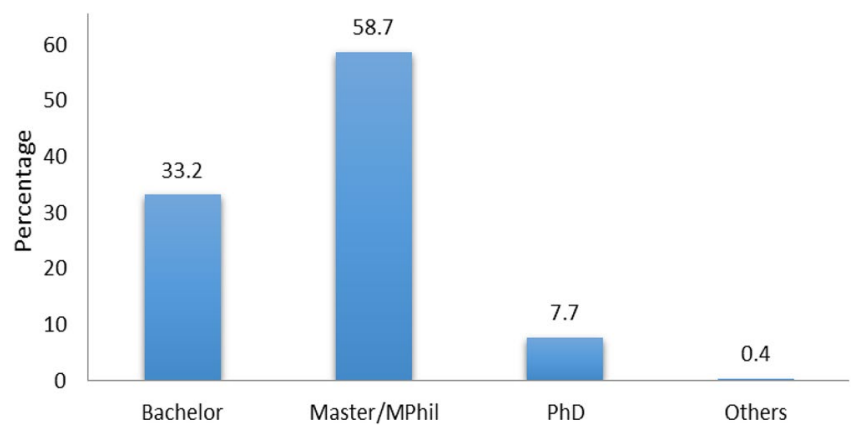

Figure 3. Percentage of qualification wise responses. The bar chart represents percentages of respondents having different qualifications.

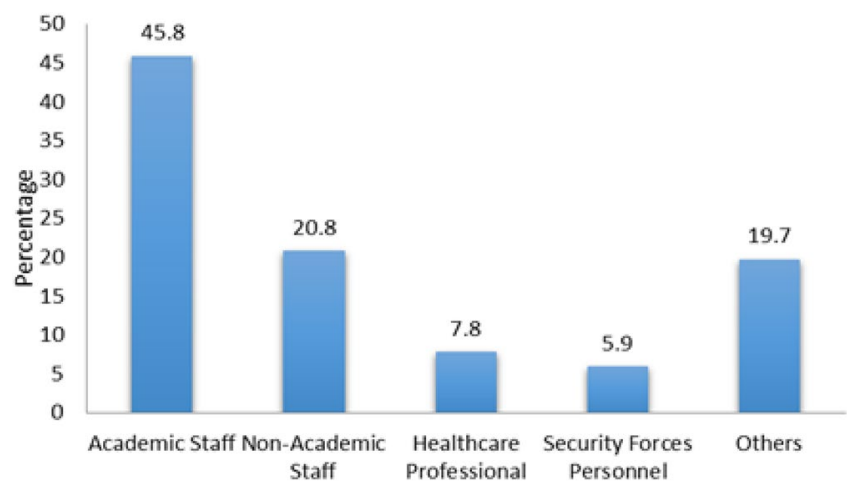

Figure 4. Percentage of profession wise responses. The bar chart represents percentages of respondents having different professions.

respondents agree that it is not seasonal and $10.34 \%$ were of view that it is seasonal while $22.26 \%$ did not know. Most of the respondents $(70.67 \%)$ were of the view that direct contact with infected persons, cough droplets, hand shaking, visiting hospitals andpublic gathering, all could cause COVID-19 infection.

In question assessing the knowledge about common signs and symptoms of COVID-19, (77.65\%) of the respondents believed that cough, fever, headache and shortness of breath are most common. Only $19.26 \%$ thought there might be symptoms other than above mentioned. In response to a query about the available vaccine of COVID-19, the majority of the study respondents $(88.43 \%)$ revealed that there is no vaccine developed yet. It was interesting to know that $(89.65 \%)$ of the respondents mentioned lung problems as a major complication of COVID-19.

Most of the respondents (85.07\%) believed that they could prevent from COVID-19 infection by doing collective practices including hand washing, wearing masks, self quarantine and social isolation however little showed inclination to single practice self quarantine $(8.22 \%)$ and hand washing $(4.77 \%)$. As laid in Table 1 majority of the respondents $(71.29 \%)$ were of the view that healthcare workers are at high risk of getting infected with COVID19. However (19.26\%) also considered field workers at risk.

In present study two questions were asked to assess the hygiene practices among people during the COVID-19 outbreak, hourly hand washing practice was reported by $(50.18 \%)$ and $(41.43 \%)$ of the respondents said that they are likely to practice it when they come home. With regards to personal hygiene $68.20 \%$ reported daily bathing.

When people were asked about the source of information about COVID-19, (29.06\%) of respondents stated that newspaper and TV were the most trusted source, (31.45\%) rely on friends, official apps, government databases, emails, social media and telecommunication authorities (10.95\%). When asked about restricted mobility during COVID-19 majority (66.78\%) were strongly agreed and (23.06\%) were agreed to the statement. From the data collected it is evident that half of the respondents (49.20\%) strongly agree to consider masks as a compulsory tool to avoid COVID-19. To evaluate the attitude of people to public events, responses showed that (95.85\%) people avoid religious gatherings, musical festivals and sport events during the COVID-19 outbreak in the country.

In query regarding satisfaction on Government arrangements for screening people at entry ports overall (21.91\%) respondents showed disagreement while more than half $(57.43 \%)$ reported satisfaction. When asked about public awareness campaigns on COVID-19 by the government, an overall $(74.83 \%)$ response was satisfactory. Only a few $(6.01 \%)$ of respondents were unsatisfied.

A prevailing myth is that Vitamin C can be directly protective against COVID-19, our study got $72 \%$ responses in affirmation, only few responses $(6.36 \%)$ in No and $20.94 \%$ were unaware about it. In a query regarding government/institutional response and arrangements to protect the community from COVID-19, most of the 
www.nature.com/scientificreports/

\begin{tabular}{|c|c|c|}
\hline Statements & Responses & No. of respondents (\%) \\
\hline \multirow{3}{*}{ What is COVID-19 } & Bacterial disease & $68(6.01)$ \\
\hline & Viral disease & $1056(93.29)$ \\
\hline & Others & $3(0.27)$ \\
\hline \multirow{4}{*}{ Number of COVID-19 patients in your area as per your knowledge } & 0 Case & $409(36.13)$ \\
\hline & $10-50$ & $114(10.07)$ \\
\hline & No idea & $188(16.61)$ \\
\hline & No response & $8(0.71)$ \\
\hline \multirow{4}{*}{ Your opinion on the possible Origin of COVID-19? } & Bat & $514(45.41)$ \\
\hline & Bat and snake & $14(1.24)$ \\
\hline & I think COVID-19 is a "Man Made Biological Weapon" & $63(5.57)$ \\
\hline & No response & $17(1.5)$ \\
\hline \multirow{5}{*}{ Is COVID-19 seasonal? } & Don't know & $252(22.26)$ \\
\hline & May be & $10(0.88)$ \\
\hline & No & $745(65.81)$ \\
\hline & Yes & $117(10.34)$ \\
\hline & No response & $8(0.71)$ \\
\hline \multirow{3}{*}{ What are the Possible Ways that you may get Infected with COVID-19? } & Cough droplets & $9(0.8)$ \\
\hline & $\begin{array}{l}\text { Cough droplets, hand shaking, quarantine areas, hospitals and public } \\
\text { gathering }\end{array}$ & $940(83.04)$ \\
\hline & Direct contact with infected person & $81(7.16)$ \\
\hline \multirow{4}{*}{ What are the common symptoms of COVID-19? } & Fever, cough, flue and shortness of breath & $999(88.25)$ \\
\hline & Flue & $23(2.03)$ \\
\hline & Shortness of breath & $86(7.6)$ \\
\hline & Others & $6(0.53)$ \\
\hline \multirow{4}{*}{ Is vitamin $\mathrm{C}$ protective against COVID-19? } & Don’t know & $237(20.94)$ \\
\hline & No & $72(6.36)$ \\
\hline & Yes & $815(72)$ \\
\hline & No response & $8(0.71)$ \\
\hline \multirow{4}{*}{ Is there any vaccine available for the cure of COVID- 19 ? } & Don't know & $94(8.3)$ \\
\hline & No & $1001(88.43)$ \\
\hline & Yes & $30(2.65)$ \\
\hline & No response & $7(0.62)$ \\
\hline \multirow{6}{*}{ What are the possible complications of COVID-19? } & Don't know & $3(0.27)$ \\
\hline & Heart problem & $10(0.88)$ \\
\hline & Heart problem, lungs problem and renal problem & $74(6.54)$ \\
\hline & Lungs problem & $975(86.13)$ \\
\hline & Lungs problem and renal problem & $57(5.04)$ \\
\hline & No response & $13(1.15)$ \\
\hline
\end{tabular}


What are the Method(s) that could be useful in preventing COVID-19?

\begin{tabular}{l} 
Hand sanitizing/washing \\
\hline Self-quarantine \\
\hline Wearing masks \\
\hline $\begin{array}{l}\text { Wearing masks, hand sanitizing/washing, disinfection, social distancing, self } \\
\text { quarantine }\end{array}$ \\
\hline No response \\
Academic professionals \\
\hline Armed forced \\
\hline Field workers
\end{tabular}

Which occupation is at the most risk of getting COVID-19?

Field workers, Health care workers, Academic professionals, Armed forced

Health care workers

No response

After every hour

After every hour, as and when I come back from outside

How often you disinfect/wash hands in a day?

After every hour, as and when I come back from outside, before eating

$963(85.07)$

$11(0.97)$

$42(3.71)$

35 (3.09)

$212(18.73)$

$14(1.24)$

$815(72)$

14 (1.24)

$559(49.38)$

$1(0.09)$

Before eating

$477(42.14)$

Rarely

No response

Daily

Once a week

How often you take shower?

Thrice a week

Twice a week

No response

Facebook

Friends

Friends, official apps/government databases, Email, WhatsApp, Facebook,

Telecommunication Authorities

Newspaper, TV

Official Apps/Government databases

Telecommunication authorities

$59(5.21)$

$19(1.68)$

$17(1.5)$

$773(68.29)$

$22(1.94)$

$218(19.26)$

97 (8.57)

22 (1.94)

$55(4.86)$

20 (1.77)

$356(31.45)$

329 (29.06)

$28(2.47)$

$10(0.88)$

TV, Friends, WhatsApp, Facebook

$58(5.12)$

TV, Official Apps/government databases

$66(5.83)$

TV, WhatsApp

WhatsApp, Facebook

Others

No response

Agree

Disagree

Neutral

Strongly agree

Strongly disagree

No response

Agree

Disagree

Neutral

Strongly agree

Strongly disagree

No response

No

24 (10.95)

$60(5.3)$

$7(0.62)$

19 (1.68)

$261(23.06)$

14 (1.24)

$73(6.45)$

$756(66.78)$

$8(0.71)$

$20(1.77)$

$326(28.8)$

$83(7.33)$

Wearing masks is compulsory to avoid COVID-19

Public events; like religious gatherings, musical festivals or sport should be avoided these days

Yes

No response

Neutral

42 (12.54)

557 (49.2)

5 (0.44)

19 (1.68)

26 (2.3)

1085 (95.85)

21 (1.86)

215 (18.99)

Satisfied

334 (29.51)

$141(12.46)$

Satisfied with the government arrangements for screening people at airports,

Unsatisfied

Very dissatisfied

$107(9.45)$

Very satisfied

No response 


\begin{tabular}{|c|c|c|}
\hline Statements & Responses & No. of respondents (\%) \\
\hline \multirow{6}{*}{$\begin{array}{l}\text { You feelings about public awareness campaigns on COVID- } 19 \text { by the } \\
\text { government }\end{array}$} & Neutral & $144(12.72)$ \\
\hline & Satisfied & $534(47.17)$ \\
\hline & Strongly dissatisfied & $19(1.68)$ \\
\hline & Strongly satisfied & $335(29.59)$ \\
\hline & Unsatisfied & $72(6.36)$ \\
\hline & No response & $28(2.47)$ \\
\hline \multirow{4}{*}{$\begin{array}{l}\text { Government/institutional response and arrangements to protect community } \\
\text { from COVID-19 outbreak? }\end{array}$} & Don't meet my expectations & $173(15.28)$ \\
\hline & Meet my expectations & $312(27.56)$ \\
\hline & Somewhat meet my expectations & $620(54.77)$ \\
\hline & No response & $27(2.39)$ \\
\hline \multirow{3}{*}{ Do closing institutions/lock-down pose any effect on your productivity? } & No & $279(24.65)$ \\
\hline & Yes & $827(73.06)$ \\
\hline & No response & $26(2.3)$ \\
\hline \multirow{4}{*}{ Current situation is stressful to you } & Moderately stressful & $581(51.33)$ \\
\hline & Not stressful & $115(10.16)$ \\
\hline & Very stressful & $412(36.4)$ \\
\hline & No response & $24(2.12)$ \\
\hline \multirow{7}{*}{ Staying at home caused any of the following situation(s) in me } & Anxiety/depression, fatigueless & $274(24.2)$ \\
\hline & Anxiety/depression, fear, blood pressure issues, fatigueless & $229(20.23)$ \\
\hline & Fatigueless & $97(8.57)$ \\
\hline & Fear & $115(10.16)$ \\
\hline & Loneliness, fatigueless & $153(13.52)$ \\
\hline & None & $99(8.75)$ \\
\hline & No response & $165(14.58)$ \\
\hline \multirow{9}{*}{ I Relax myself in current situation of COVID-19 by } & Do religious practices & $118(10.42)$ \\
\hline & Do religious practices, play indoor game (individually) & $55(4.86)$ \\
\hline & Play indoor game (individually) & $33(2.92)$ \\
\hline & Sleep most of the time & $100(8.83)$ \\
\hline & $\begin{array}{l}\text { Sleep most of the time, watch TV/social media/news, do religious practices, } \\
\text { play indoor game (individually) }\end{array}$ & $299(26.41)$ \\
\hline & Watch TV/social media/news & $256(22.61)$ \\
\hline & $\begin{array}{l}\text { Watch TV/social media/news, do religious practices, play indoor game } \\
\text { (individually) }\end{array}$ & $154(13.6)$ \\
\hline & Others & $78(6.89)$ \\
\hline & No response & $39(3.45)$ \\
\hline \multirow{5}{*}{ When the COVID-19 may be over from your area, your perception? } & May persist long & $251(22.17)$ \\
\hline & No idea & $448(39.58)$ \\
\hline & Very soon & $400(35.34)$ \\
\hline & Will persist long & $8(0.71)$ \\
\hline & No response & $25(2.21)$ \\
\hline
\end{tabular}

Table 1. Question wise responses and percentages.

respondents $(27.56 \%, 54.77 \%)$ showed their trust on these activities. However, dissatisfaction was also expressed by $(15.28 \%)$ by saying that government/institutional responses do not meet their expectations. A large number (73.06\%) of the participants of study stated that closure of their institutions/lockdown to contain COVID-19 has affected their productivity.

In our study more than half of the respondents (51.33\%) said that the current situation is moderately stressful while for $(36.40 \%)$ it is stressful. Response of $(10.16 \%)$ showed that they are not affected by the current situation of COVID-19. Partial lock down is implemented in the country due to the pandemic situation of COVID-19, our study assessed that staying at home caused anxiety, depression and fatigue in $(24.2 \%)$ of participants while $(20.23 \%)$ expressed fear and blood pressure issues along with above mentioned problems, $13.52 \%$ fear and loneliness and $10.16 \%$ expressed only fear. The overall observation of the activities revealed that while staying at home $(44.52 \%)$ people spend time sleeping, on social media and TV news. While (55.48\%) were engaged in other activities. A query "when the COVID-19 may be over from your area? Got mixed responses, (22.88\%) said that it will persist long, (36.40\%) showed no idea and (33.92\%) said that it will go away very soon.

Distribution of responses with respect to age, gender, educational level and occupation. In Table 2 we considered the responses to the questions with respect to age, gender, educational level and occupation. Pearson chi-square test showed the chi-square values and significant mean difference for each question. 


\begin{tabular}{|c|c|c|c|c|c|}
\hline \multicolumn{2}{|l|}{ Statements } & \multirow{2}{*}{\begin{tabular}{|l|} 
Age \\
52.622 \\
\end{tabular}} & \multirow{2}{*}{$\begin{array}{l}\text { Gender } \\
7.200\end{array}$} & \multirow{2}{*}{$\begin{array}{l}\text { Educational level } \\
18.034\end{array}$} & \multirow{2}{*}{\begin{tabular}{|l|} 
Occupation \\
17.151
\end{tabular}} \\
\hline What is COVID 10 & Chi-square & & & & \\
\hline What is COVID-19 & Sig & $0.000^{*}$ & 0.303 & 0.261 & 0.144 \\
\hline \multirow{2}{*}{ Number of COVID-19 patients in your area as per your knowledge } & Chi-square & 32.757 & 16.640 & 292.033 & 33.259 \\
\hline & Sig & $0.005^{*}$ & 0.083 & $0.000^{*}$ & $0.032^{*}$ \\
\hline \multirow{2}{*}{ Your opinion on the possible origin of COVID-19? } & Chi-square & 28.926 & 29.438 & 44.689 & 47.362 \\
\hline & Sig & 0.116 & $0.009^{*}$ & 0.126 & $0.013^{*}$ \\
\hline \multirow{2}{*}{ Is COVID-19 seasonal? } & Chi-square & 23.63 & 4.905 & 135.891 & 21.775 \\
\hline & Sig & 0.072 & 0.897 & $0.000^{*}$ & 0.353 \\
\hline \multirow{2}{*}{$\begin{array}{l}\text { What are the possible ways that you may get infected with COVID- } \\
19 \text { ? }\end{array}$} & Chi-square & 49.628 & 33.385 & 99.538 & 46.9 \\
\hline & Sig & $0.002^{*}$ & $0.007^{*}$ & $0.000^{*}$ & $0.043^{*}$ \\
\hline \multirow{2}{*}{ What are the common symptoms of COVID-19? } & Chi-square & 41.934 & 37.441 & 110.186 & 30.978 \\
\hline & Sig & $0.004^{*}$ & $0.001^{*}$ & $0.000^{*}$ & 0.318 \\
\hline \multirow{2}{*}{ Is vitamin $\mathrm{C}$ protective against COVID-19? } & Chi-square & 14.193 & 8.349 & 78.59 & 33.663 \\
\hline & Sig & 0.116 & 0.214 & $0.000^{*}$ & $0.001^{*}$ \\
\hline \multirow{2}{*}{ Is there any vaccine available for the cure of COVID- $19 ?$} & Chi-square & 30.06 & 9.884 & 42.53 & 17.339 \\
\hline & Sig & $0.000^{*}$ & 0.13 & $0.000^{*}$ & 0.137 \\
\hline \multirow{2}{*}{ What are the possible complications of COVID-19? } & Chi-square & 20.319 & 0.989 & 49.692 & 19.13 \\
\hline & Sig & 0.16 & 1 & $0.002^{*}$ & 0.513 \\
\hline \multirow{2}{*}{$\begin{array}{l}\text { What are the method(s) that could be useful in preventing COVID- } \\
19 \text { ? }\end{array}$} & Chi-square & 28.961 & 15.97 & 46.232 & 30.064 \\
\hline & Sig & $0.004^{*}$ & $0.043^{*}$ & $0.001^{*}$ & $0.018^{*}$ \\
\hline \multirow{2}{*}{ Which occupation is at the most risk of getting COVID-19? } & Chi-square & 21.371 & 7.985 & 59.146 & 37.776 \\
\hline & Sig & 0.125 & 0.63 & $0.000^{*}$ & $0.009^{*}$ \\
\hline \multirow{2}{*}{ How often you disinfect/wash hands in a day? } & Chi-square & 28.119 & 39.145 & 31.686 & 22.502 \\
\hline & Sig & $0.021^{*}$ & $0.000^{*}$ & 0.167 & 0.314 \\
\hline \multirow{2}{*}{ How often you take Shower? } & Chi-square & 24.995 & 87.276 & 29.669 & 29.564 \\
\hline & Sig & $0.015^{*}$ & $0.000^{*}$ & 0.075 & $0.020 \mathrm{a}^{*}$ \\
\hline \multirow{2}{*}{ You got the initial information about COVID-19 through } & Chi-square & 36.805 & 27.807 & 119.634 & 59.561 \\
\hline & Sig & 0.297 & 0.182 & $0.000^{*}$ & 0.059 \\
\hline \multirow{2}{*}{ Spread of COVID-19 has restricted my mobility } & Chi-square & 75.168 & 7.141 & 54.415 & 41.766 \\
\hline & Sig & $0.000^{*}$ & 0.712 & $0.001^{*}$ & $0.003^{*}$ \\
\hline \multirow{2}{*}{ Wearing masks is compulsory to avoid COVID-19 } & Chi-square & 35.004 & 6.691 & 34.043 & 24.749 \\
\hline & Sig & $0.002^{*}$ & 0.754 & 0.107 & 0.211 \\
\hline \multirow{2}{*}{$\begin{array}{l}\text { Public events; like religious gatherings musical festivals or sport } \\
\text { should be avoided these days }\end{array}$} & Chi-square & 10.156 & 4.014 & 48.881 & 7.135 \\
\hline & Sig & 0.118 & 0.404 & $0.000^{*}$ & $0.522^{\mathrm{a}}$ \\
\hline Satisfied with the government arrangements for screening people at & Chi-square & 55.749 & 21.707 & 64.885 & 23.659 \\
\hline airports sea ports and entry points & Sig & $0.000^{*}$ & $0.017^{*}$ & $0.000^{*}$ & 0.258 \\
\hline You feelings about public awareness campaigns on COVID-19 by & Chi-square & 49.381 & 28.465 & 170.648 & 74.416 \\
\hline the Government & Sig & $0.005^{*}$ & 0.055 & $0.000^{*}$ & $0.000^{*}$ \\
\hline Government/institutional response and arrangements to protect & Chi-square & 28 & 7.651 & 34.03 & 14.634 \\
\hline community from COVID-19 outbreak? & Sig & $0.001^{*}$ & 0.265 & $0.003^{*}$ & 0.262 \\
\hline Does closing institutions/lock-down pose any effect on your & Chi-square & 15.176 & 3.41 & 24.776 & 6.592 \\
\hline productivity? & Sig & 0.086 & 0.756 & 0.053 & 0.883 \\
\hline Current situation is stressul to you & Chi-square & 21.343 & 32.453 & 44.974 & 13.617 \\
\hline Current situation is stressful to you & Sig & $0.011^{*}$ & $0.000^{*}$ & $0.000^{*}$ & $0.326^{\mathrm{a}}$ \\
\hline Staving at home caused any of the following situntion (s) in me & Chi-square & 35.795 & 19.42 & 81.849 & 41.436 \\
\hline Staying at nome caused any or the rollowing situation(s) in me & Sig & $0.023^{\star}$ & 0.15 & $0.000^{*}$ & $0.049^{*}$ \\
\hline ax mucelf in current situation of $C O V$ D 19 & Chi-square & 38.6 & 64.187 & 64.987 & 84.135 \\
\hline 1 Relax myself in current situation of COVID-19 by & Sig & 0.621 & $0.000^{*}$ & 0.647 & $0.009^{*}$ \\
\hline When the COVID-19 mav be over from wour & Chi-square & 65.676 & 17.279 & 48.657 & 72.316 \\
\hline When the COVID-19 may be over from your area your percept & Sig & $0.011^{*}$ & 0.943 & 0.976 & 0.07 \\
\hline
\end{tabular}

Table 2. Pearson Chi-square tests. ${ }^{\star}$ The Chi-square is significant (two variables are not independent) at the 0.05 level. 
Mean difference value of 0.05 or less was considered statistically significant. Variation and similarity of responses were assessed by this test. With respect to basic knowledge of COVID-19, significant variation was observed with age group $\left(0.000^{\star}\right)$ Query regarding the prevalence of COVID-19 got significant variations for all variables except gender responses (0.083), Significant variation was observed with respect to query regarding the possible origin of COVID-19 in gender and occupation responses $\left(0.009^{*}, 0.013^{\star}\right)$. A query about seasonality of COVID19 got significant results only in educational group responses $\left(0.000^{\star}\right)$.

On questions concerning possible ways of getting infected with COVID-19 there was also significant variability in responses of all variables i.e., age, gender, educational level and occupation $\left(0.002^{\star} 0.007^{\star} 0.000^{\star}\right.$ $\left.0.043^{\star}\right)$. On the question about common signs and symptoms of COVID-19, we found significant variations in responses with respect to age, gender and educational groups $\left(0.004^{\star} 0.001^{\star} 0.000^{*}\right)$. Interestingly myth about prevention of vitamin C against COVID-19, gathered significant variations in responses from educational and occupational groups $\left(0.000^{\star} 0.001^{\star}\right)$. For knowing about the vaccine availability and possible complications of COVID-19, significant variations were observed with respect to age and educational group $\left(0.000^{*}, 0.000^{\star}\right.$, $\left.0.002^{\star}\right)$. It is clear from the significant responses that people are well aware of the protective measures against COVID-19 with respect to all variables in Table $2\left(0.004^{\star} 0.043^{\star} 0.0010 .018^{\star}\right)$.

When asked about the occupation at risk to COVID-19, significant variations were observed from educational and occupation groups $\left(0.000^{\star} 0.009^{\star}\right)$. In our study significant variations were observed in responses to queries about disinfecting practices with regard to age, gender and educational groups. Variation in responses were observed from educational groups $\left(0.000^{\star}\right)$ when people were asked about the source of getting information about COVID-19. Significant variations in the responses from all variables in Table 2 showed that COVID-19 has restricted their mobility except in gender group $\left(0.000^{*} 0.7120 .001^{*} 0.003^{\star}\right)$. Response from age group with significant value $\left(0.002^{\star}\right)$ showed that for this group wearing a mask is compulsory as a protective measure against COVID-19. We observed significant variation in responses $\left(0.000^{\star}\right)$ from different educational groups when they were asked to avoid public gatherings to contain COVID-19.

Significant variations were gathered in responses with respect to almost all variables when participants were asked about the government arrangements taken for screening at entry point, people awareness campaigns and government and institutional response to protect the community from COVID-19 (Table 2). Insignificant variations in responses $(0.0860 .7560 .0530 .883)$ showed that closing of institutes did not pose any effect on respondent's productivity. However current situation is stressful for all variables except occupational group as shown by significant value in Table $2\left(0.011^{\star} 0.000^{\star} 0.000^{\star}\right)$.

Significant and insignificant both variations were observed in the responses when participants were asked about their activities during partial lock down (Table 2). On the question when COVID-19 outbreak will go away from their area, significant variation in responses was observed with respect to age group $\left(0.011^{\star}\right)$.

\section{Discussion}

This study was started during the first wave (March 2020) of COVID-19 in Pakistan and authorities imposed the complete lockdown and aggressive measures to proclaim the spread of disease. Through a self-designed questionnaire, data regarding the awareness pertaining to the origin, symptoms, spread, control, and prevention of COVID-19 was collected in this study. It is important to consider that the highest number of responses were received by individuals falling in the age group of 25-40 years, having Master/MPhil as their highest education and belonging to the academic profession from different regions of Pakistan (Fig. 5). Results indicate a high level of right awareness among individuals, especially regarding the cause (93.29\%), the routes of transmission (70.76\%), the signs and symptoms $(77.65 \%)$, preventive strategies $(\sim 85 \%)$ and health complications due to the infection (89.65\%). A similar study has conducted in Punjab revealed the satisfactory response of health care professionals regarding COVID-19 awareness, spread, signs and symptoms and complications. This may be attributed to the authorities who persistently provided COVID-19 information to not only health professionals ${ }^{12}$ but to general public too.

Interestingly, the source of information for the respondents regarding COVID-19 are predominantly modern media (60.51\%). This is supported by another study conducted in Pakistan which reported that majority of the respondents of study used social media as their major source of information ${ }^{13}$. A fear of COVID-19 is a major mental health problem not only in Pakistan but around the globe. It is key to understand that the outbreak itself, and the consequential lockdown, has caused significant psychological impact on the society with $87.73 \%$ people reporting the situation to be stressful, leading them to face anxiety, depression and fatigue. This fear may be attributed to closure of educational institutes, private hospitals and ban on intra and intercity transport ${ }^{14}$.

According to our results, the percentage incidence of new cases reported per day have reduced since the first few cases and the launch of the National Action Plan in Pakistan. However, this factor is independent of the fact that there are limited screening facilities available in the country. On one hand, sharing of border and vast trade relations with China where COVID-19 initiated and Iran which has a high number of infected individuals, and lack of ample medical facilities and health awareness in Pakistan on the other hand, the country is in a unique situation $^{15}$. In view of the lack of appropriate prevention and control policies at educational and medical organizations, effective awareness campaigns at both national and community level were launched under the National Action Plan for COVID-19 proposed by the Ministry of Health Services, Regulation and Coordination, Government of Pakistan ${ }^{10}$. This study conducted almost a month after the first reported COVID-19 case in Pakistan aimed at evaluating the general awareness of professionals regarding this pandemic. Results reported also have an outcome of assessing effectiveness of the National Action Plan and could be used as a pointer for further course of action. 


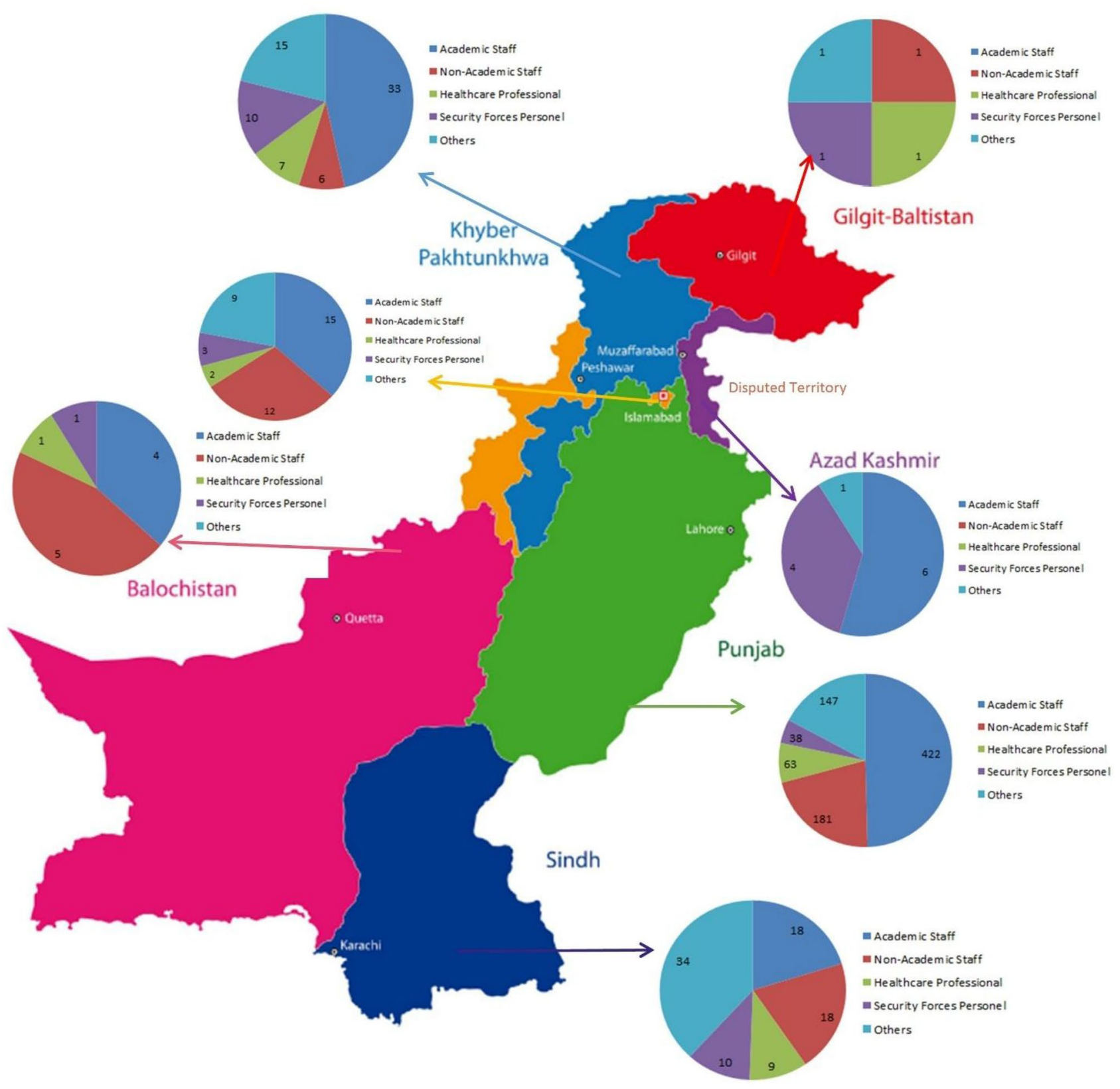

Figure 5. Respondents' distribution province wise. (http://clipart-library.com/clipart/pc5oXeaoi.htm).

\section{Methods}

Data collection. The data presented in this paper was obtained one month after the outbreak of COVID19 in Pakistan as the first case was reported on February 26, 2020. Information about COVID-19 outbreak was obtained by a self-designed questionnaire that was distributed via online portal of Virtual University of Pakistan, emails and other sources of communication (mainly WhatsApp groups) among professionals of different institutions across the country. The study was approved by the Departmental Ethical Committee of the Department of Molecular Biology, Virtual University of Pakistan, which conforms tothe Declaration of Helsinki and all methods in this study were carried in accordance with relevant guidelines. Questionnaire was developed to assess the awareness about the basic knowledge, prevalence in the residing area, mode of transmission of infection, common signs and symptoms, complications, preventive measures, effects on personal health, perceptions, government response and arrangement on COVID-19 outbreak. The questionnaire was filled by individuals voluntarily with a prior informed consent taken in the form of a covering letter shared along with the questionnaire.

In the current scenario respondents from different cities of Pakistan were included in this study. Demographic data including age, gender, educational level and occupation of the participants were recorded. Query was addressed about the number of infected people in the residing area of the participants. In the questionnaire, respondents were inquired about the origin, common signs and symptoms and the possible ways to get infected with COVID-19. At the time of this global emergency several myths have been circulated about COVID-19, 
participants were asked about the cure, vaccination and seasonality of its spread. Questions investigating the respondents' knowledge about infection complications, effective preventive measures and common practices that need to be done in this pandemic were assessed. Questionnaire also contained questions about personal hygiene to analyze personal health efforts.

Correlation of people's behavior towards the current partial lockdown situation in the country was evaluated by different questions. To evaluate the risk of social and religious gatherings in the present scenario, respondents were asked whether they avoid these public events or not? A range of questions was included in the questionnaire on their opinion of the awareness campaigns, arrangement of screening, preventive strategies and policies at national and institutional level.

To those who are restricted to move out due to quarantine to avoid viral spread, a series of questions was asked to evaluate the level of stress and activities they are doing in this time of public health crises. A partial lockdown strategy has been applied to almost all institutes across the country, a question was also asked regarding productivity of the respondents. Within the questionnaire respondents were asked which source of information they rely for the latest update of COVID-19 across the country as well as globe.

To avoid the community transfer social distancing strategy has been implemented in almost all institutions and in this situation online mode of education has been launched to reduce the knowledge gap. People's response was recorded on effectiveness of online mode of education in their working institutes.

For this study only one response was accepted from one participant and incomplete responses were excluded. Current faculty, academic, non-academic staff, healthcare professionals and security professionals were included in this survey.

Statistical analysis. Data obtained was statistically analyzed by computer software SPSS version 21 . Results were presented in frequency and percentage. Pearson chi-square test was performed to analyze the mean difference between variables.

\section{Conclusion}

Deeming public awareness to be crucial in preventing the spread of COVID-19, which otherwise lacks effective treatment and preventive measures, vast public awareness campaigns played a key role in the fight against it.The awareness, attitude and practices for the survival of humans have been influenced by the COVID-19 pandemic. We being the residents of the developing country are still fighting against COVID-19 and for the ultimate accomplishment, community should follow the public health measures. The current study reveals the level of awareness regarding knowledge, attitude and preventative practices against COVID-19 among professionals from different fields in Pakistan.The results of our study reveal that public awareness campaigns under the National Action Plan for COVID-19 of the Pakistani government have led to significant awareness of the young, educated and professional class in Pakistan. It was evident that the community's overall response was satisfactory with respect to awareness about the symptoms, mode of transmission and precautionary measures of COVID-19. And this positive approach of public also influences the practices towards COVID-19 as the majority of the people showed their willingness to follow the guidelines set by the government.

Received: 30 March 2020; Accepted: 13 July 2021

Published online: 02 September 2021

\section{References}

1. Deng, S. Q. \& Peng, H. J. Characteristics of and public health responses to the coronavirus disease 2019 outbreak in China. J. Clin. Med. 9(2), 575. https://doi.org/10.3390/jcm9020575 (2020).

2. $\mathrm{Zu}, \mathrm{Z}$. Y. et al. Coronavirus disease 2019 (COVID-19): A perspective from China. Radiology https://doi.org/10.1148/radiol.20202 00490 (2020).

3. Millán-Oñate, J. et al. A new emerging zoonotic virus of concern: The 2019 novel Coronavirus (COVID-19). Infection https://doi. org/10.22354/in.v24i3.848 (2020).

4. Phelan, A. L., Katz, R. \& Gostin, L. O. The novel coronavirus originating in Wuhan, China: Challenges for global health governance. JAMA 323(8), 709-710. https://doi.org/10.1001/jama.2020.1097 (2020).

5. Anzai, A. et al. Assessing the impact of reduced travel on exportation dynamics of novel coronavirus infection (COVID-19). J. Clin. Med. 9(2), 601. https://doi.org/10.3390/jcm9020601 (2020).

6. Rocklöv, J., Sjödin, H. \& Wilder-Smith, A. COVID-19 outbreak on the Diamond Princess cruise ship: Estimating the epidemic potential and effectiveness of public health countermeasures. J. Travel Med. https://doi.org/10.1093/jtm/taaa030 (2020).

7. Dagia, N. Pakistan facing major COVID-19 challenge: WHO. Express Tribune (2020).

8. Xinhua. Number of COVID-19 cases in Pakistan surpasses 100. The Nation. (2020).

9. Storr, J. et al. Core components for effective infection prevention and control programmes: New WHO evidence-based recommendations. Antimicrob. Resist. Infect. Control. 6(1), 6. https://doi.org/10.1186/s13756-016-0149-9 (2017).

10. Ministry of National Health Services, Regulations and Coordination. National Action Plan for Corona virus disease (COVID-19) Pakistan (2020).

11. Park, Y.-S. et al. The first case of the 2015 Korean Middle East respiratory syndrome outbreak. Epidemiol. Health. 37, 1-5. https:// doi.org/10.4178/epih/e2015049 (2015).

12. Salman, M. et al. Knowledge, attitude and preventive practices related to COVID-19 among health professionals of Punjab province of Pakistan. J. Infect. Dev. Ctries. 14(07), 707-712 (2020).

13. Saqlain, M., Munir, M. M., Rehman, S. U., Gulzar, A., Naz, S., Ahmed, Z., Tahir, A. H. \& Mashhood, M. Knowledge, attitude and practice among healthcare professionals regarding COVID-19: A cross-sectional survey from Pakistan. J. Hosp. Infect. (2020).

14. Waqas, M., Hania, A. \& Hongbo, L. Psychological predictors of anxious responses to the COVID-19 pandemic: Evidence from Pakistan. Psychiatry Investig. 17(11), 1096 (2020).

15. Khan, S., Khan, M., Maqsood, K., Hussain, T. \& Zeeshan, M. Is Pakistan prepared for the COVID-19 epidemic? A questionnairebased survey. J. Med. Virol. 92(7), 824-832 (2020). 


\section{Acknowledgements}

Authors are grateful to Quality Enhancement Cell and ICT department of the Virtual University of Pakistan for their help in survey design and launch at national level. We are thankful to Mr. Mirza Jawad ulHasnain, Mr. RizwanSaleem Sandhu and Ms. Ammara Hashmi from Virtual University of Pakistan for their contributions. We thank various academic and professional social media groups for sharing and responding to the survey.

\section{Author contributions}

All authors contributed equally in the conception and design of this research. Analyses in the article and writing of the manuscript were also performed equally.

\section{Funding}

No funding source to be mentioned.

\section{Competing interests}

The authors declare no competing interests.

\section{Additional information}

Correspondence and requests for materials should be addressed to T.H.

Reprints and permissions information is available at www.nature.com/reprints.

Publisher's note Springer Nature remains neutral with regard to jurisdictional claims in published maps and institutional affiliations.

(c) (i) Open Access This article is licensed under a Creative Commons Attribution 4.0 International License, which permits use, sharing, adaptation, distribution and reproduction in any medium or format, as long as you give appropriate credit to the original author(s) and the source, provide a link to the Creative Commons licence, and indicate if changes were made. The images or other third party material in this article are included in the article's Creative Commons licence, unless indicated otherwise in a credit line to the material. If material is not included in the article's Creative Commons licence and your intended use is not permitted by statutory regulation or exceeds the permitted use, you will need to obtain permission directly from the copyright holder. To view a copy of this licence, visit http://creativecommons.org/licenses/by/4.0/.

(C) The Author(s) 2021 